\title{
PENDIDIKAN KARAKTER DI PERGURUAN TINGGI DALAM PEMBANGUNAN DI ERA MEA
}

\author{
Joko Mursitho \\ Universitas Muhammadiyah Metro \\ Murshito@yahoo.co.id
}

\begin{abstract}
The experience model approach, social media, and individual approach called success when; firstly, the lecturers have ability to present their material more variative and interesting because it is integrated with character, through the implementation of inquiry model, social model, and individual model. In applying the Tri Darma's values of University the lecturers can set the material better. Secondly, exciting presentations are able to decrease the discrepancy relationship among lecturers and learners. Thirdly, lecturers can make contact with other better institutions both profit and non profit to make link between campus and employment which are the real life in society.
\end{abstract}

Key words: Higher Education, Characther of Education, The three main purpose of College.

\begin{abstract}
Abstrak
Keberhasilan pendekatan model pengalaman, model sosial, dan model individual, manakala; Pertama, Para dosen akan memiliki kemampuan menyajikan materi yang diampunya yang lebih variatif dan menarik karena diintegrasikan dengan pendidikan karakter, melalui penerapan inquiry model, sosial model, dan individual model. Dosen dapat mengemas bahan ajar yang lebih baik dalam mengaplikasikan nilai-nilai yang terkandung dalam Tri Darma Perguruan Tinggi. Kedua, Dengan penyajian yang menarik maka akan dapat mengurangi kesenjangan hubungan antara dosen dan mahasiswa. Ketiga, Dosen dapat melakukan pendekatan dan bekerjasama dengan instansi/lembaga lain baik yang profit maupun non profit untuk menjembatani kehidupan kampus dan lapangan kerja yang merupakan kehidupan yang sebenarnya di masyarakat.
\end{abstract}

Kata Kunci: Pendidikan Tinggi, Pendidikan Karakter, Tri Dharma Perguruan Tinggi

\section{Pendahuluan}

Karakter menurut Thomas Lickona ${ }^{1}$ adalah harmoninya antara moral knowing, moral feeling, dan moral action dalam pengertian bahwa seseorang yang berkarakter itu mempunyai pikiran yang baik (thinking the good), memiliki perasaan yang baik (feeling the good), dan juga berperilaku baik (acting the good). ${ }^{2}$ Pentingnya pendidikan karakter itu juga ditegaskan Alexis de Toqueville "...each new generation is a new people that must acquire the knowledge, learn the skills, and develop the dispositions or traits of private and public character that undergird a constitutional democracy. Those dispositions must be fostered and nurtured by word and

${ }^{1}$ Lickona, Thomas dan Matthew Davidson, Smart $\mathcal{E}$ Good High School: Integrating Excellence and Ethics for Success in Schools, Work, and Beyond. Cortland: Center for 4th and 5th Rs, 2004.

2 J. Schwartz, Merle (ed), Effective Character Education: A Guidebook for Future Educators, New York: McGraw-Hill Companies, 2008. 
study and by the power of example. Democracy is not a "machine that would go of itself," but must be consciously reproduced, one generation after another."3

Model pendidikan karakter yang dirumuskan oleh Dasim Budimansyah, Prof. Dr. M.Si. dkk. dari Universitas Pendidikan Indonesia dilakukan melalui tiga modus. Pertama, melalui penguatan Pendidikan Kewarganegaraan dalam kapasitasnya sebagai mata kuliah umum yang menjadi menu wajib bagi seluruh mahasiswa yang diberikan pada masa-masa awal mahasiswa belajar di bangku kuliah. Model yang pertama ini diarahkan untuk meningkatkan kualitas pembelajaran dengan menggunakan inovasi pembelajaran Project Citizen untuk membina karakter demokratis dan partisipatif. Kedua, mengoptimalkan layanan bimbingan konseling kepada para mahasiswa baik di dalam maupun di luar perkuliahan yang diarahkan untuk mendorong para mahasiswa agar mampu menyelesaikan masalah dirinya sendiri dan tumbuhnya kesadaran akan segala potensi yang dimilikinya. Melalui berbagai pendekatan, game, dan strategi, potensi-potensi mahasiswa dapat dikembangkan secara optimal, sehingga mahasiswa memiliki kepercayaan diri untuk berkembang. Ketiga, menyelenggarakan Kuliah Kerja Nyata (KKN) Tematik yang merupakan menu wajib pada masa-masa akhir mahasiswa menimba ilmu. Pendidikan karakter melalui KKN Tematik diarahkan untuk memantapkan berbagai karakater baik yang telah dibina di universitas melalui proses belajar sambil melakoni (learning by doing) dalam kehidupan masyarakat. ${ }^{4}$

Mahasiswa merupakan insan akademis yang menjadi harapan bangsa untuk menegakkan dan meneruskan perjuangan bangsa mengisi pembangunan untuk mencapai tujuan negara, sebagaimana termaktub dalam Pembukaan Undang-Undang Dasar Negara republik Indonesia.

Direktorat Jenderal Potensi Pertahanan Kementerian Pertahanan Republik Indonesia merumuskan "Persyaratan utama karakter generasi penerus bangsa" adalah:

1. Unggul dan berkualitas.

2. Memiliki martabat dan integritas.

3. Terpercaya karena memiliki kompetensi yang tinggi.

4. Berperan penting dalam berbagai bidang kehidupan guna memajukan negara dan menjamin kelangsungan berbangsa bernegara.

Dengan demikian generasi penerus ini harus memiliki sifat kepemimpinan yang baik dan dapat diandalkan.

Namun fakta menunjukkan bahwa masih banyak mahasiswa mencontek, berdemonstrasi dengan merusak lingkungan, bahkan masih banyak terjadi tawuran baik antar jurusan, antar fakultas, bahkan antar perguruan tingi.

\footnotetext{
3 Branson, E.J., 1998. Rainbow trout fry syndrome: an update. Fish Vet. J. 1998(2):63-66.

4 Aini, Neneng Siti Fatimah Nurul, "Pendidikan Karakter dalam Pemikiran Azyumardi Azra", Skripsi, Fakultas Tarbiyah dan Keguruan UIN Sunan Kalijaga Yogyakarta, 2012.
}

RI'AYAH, Vol. 01, No. 01 Januari-Juni 2016 
Direktur Jenderal Pendidikan Tinggi Kementerian Pendidikan dan Kebudayaan Djoko Santoso mengatakan hal itu dalam seminar nasional bertema "Strategi Menghadapi Konflik/Disharmoni Antar pemangku Kepentingan Perguruan Tinggi..." 5

Pertanyaannya adalah mengapa model pendekatan ini belum menghasilkan output dan impact yang baik sebagai peubah perilaku mahasiswa? Apakah komponen pelaksananya yang kurang mampu, atau program tersebut belum disosialisasikan di Perguruan Tinggi, atau program tersebut masih bersifat melangit dan belum membumi sehingga memerlukan "petunjuk teknis penyelenggaraan yang lebih detail dan rumit?"6

Kemungkinnya bahwa ketiga-tiganya bisa terjadi. Oleh karena itu pemakalah merumuskan model pendekatan yang sederhana, tidak rumit, luwes, sehingga setiap dosen bila "Mau" dapat menjabarkannya sendiri dalam bentuk kegiatan yang sangat memungkinkan dan mendorong untuk menjadi peubah perilaku mahasiswa.

\section{Inisiasi Model Pendekatan Kurikulum}

Tulisan ini mencoba untuk membuat model pendidikan karakter bagi mahasiswa di perguruan tinggi yaitu:

1. Model Penjelajahan Pengalaman (Inquiry model). Mahasiswa bila hanya diberikan bekal ilmu tanpa dibekali pengalaman untuk melaksanakan ilmunya, maka dia akan menjadi "penghafal teori/penghafal rumus/penghafal konsep yang tidak akan pernah tuntas". Oleh karena itu mahasiswa perlu diberikan pendidikan yang mendasarkan pada pengalaman. Model ini harus diintegrasikan di dalam perkuliahan yang intra kurrikuler, kokurikuler, maupun ekstra kurikuler, bahkan dimasukkan ke dalam hiden kurikuler (kurikulum tersembunyi). Pendekatan ini banyak dlakukan oleh pendidikan kepramukaan di seluruh dunia (World Organization of Scout Movement). ${ }^{7}$ Di dalam inquiry model ini terdapat 3 pendekatan di dalam berkegiatan sebagai berikut:

a. Pembelajaran berbasis pengalaman (Inquiry based learning):

Melalui penerapan praktis (A Practical Application). Pendidikan berdasarkan pengalaman dengan aplikasi penerapan, belum banyak diterapkan di Perguruan Tinggi. Bagaimana belajar sambil bekerja (learning by doing); melalui belajar untuk mencari tahu dan bukan belajar untuk diberi tahu (learning to know); (learning to do). Di sini mereka belajar untuk terampil dengan menguasai berbagai kecakapan

${ }^{5}$ Lihat, Kompas, 18/2/2013

6 Baden Powell. Lord,. 1922., Rovering to Success, Herbert Jenkins Ltd. 3 Duke of York Street, London, S.W.I.

7 Baden Powell. Lord.,Panduan Untuk Pembina Pramuka Penggalang, (Judulasli: Aids to Scout Masterships) disunting oleh: Mun Kusumanti, Joko Mursitho, Dadi Pakar \& Rini Palupi, Penerbit: Pustaka Tunas Media, Balai Penerbit GerakanPramuka, Jakarta. 2012

RI'AYAH, Vol. 01, No. 01 Januari-Juni 2016 
yang dibutuhkan baik kecakapan umum maupun kecakapan khusus untuk bekal hidup. Selama ini mahasiswa yang baru lulus belum memiliki keterampilan yang memadai untuk bidang kerja yang sesuai dengan jurusannya. Apalagi kenyataan bahwa banyak pekerjaan yang ternyata dikerjakan oleh lulusan yang tidak sesuai dengan bidang pekerjaan tersebut. Oleh karena itu model pembelajaran berbasis pengalaman inilah mereka dilengkapi dengan learning to live together yakni belajar untuk hidup bersama yang di dalamnya terdapat learning to earn" yakni belajar untuk mencari nafkah, dan"learning to serve" (belajar untuk memberikan pelayanan), dan melalui berbagai belajar yang tersistem tersebut mahasiswa akan learning to be belajar untuk menemukan jati dirinya.

Realisasi pembelajarannya bisa dimasukkan dalam setiap kegiatan di semua bidang studi (intra dan ko kulikuler, dengan catatan perlu ada pelatihan bagi dosen untuk memadukan setiap mata kuliahnya dengan pendidikan karakter bukan hanya dalam kegiatan verbal (lecture). Selain itu bisa dimasukkan dalam setiap kegiatan ekstra kurikuler.

Namun demikian perlu juga ada kegiatan yang sifatnya hidden curriculum (kurikulum tersembunyi). Misalnya dilakukan upacara setiap bulan di tanggal 17. Dilakukan "pendidikan kepemimpinan" yang sifatnya wajib, sehingga mahasiswa yang belum mengikuti pendidikan kepemimpinan belum boleh mengikuti skripsi.

b. Pembelajaran berbasis proyek (Project based-learning). Metode proyek ini diterapkan sebagai implikasi penerapan nilai sosial. Kegiatan tersebut dapat dilakukan oleh mahasiswa dengan membuat "proyek" teknologi terapan yang bisa dilakukan atau dimanfaatkan di bidang pendidikan, hukum, sosial, budaya, atau yang paling mudah adalah membuat hasta karya (handicraft) yang bisa dilakukan secara individu maupun kelompok.

c. Pembelajaran berbasis permasalahan dan kasus yang dihadapi (Problem based learning \& Case based learning). Kegiatan mahasiswa belum dekat dengan lingkungan social maupun lingkungan alam; mereka masih banyak dijejali dengan telaah buku-buku teks. Oleh karena itu perlu disiapkanpembelajaran yang bertumpu pada pemecahan masalah dan bagaimana mengurai kasus-kasus untuk memperoleh alternatif solusi terbaik. Latihan-latihan diberikan kepada mahasiswa dalam berbagai bentuk kegiatan pemecahan masalah yang dihadapi secara langsung atau lewat simulasi melalui diskusi-diskusi.

RI'AYAH, Vol. 01, No. 01 Januari-Juni 2016 
2. Model Pendekatan Sosial (Social Models). Hal inidilakukandengan:

a. Meningkatkan kualitas berpikir melalui belajar hidup bersama atau belajar dengan system beregu (Enhancing thinking through cooperative learning). Model pembelajaran dengan meningkatkan kualitas melalui belajar bekerjasama dengan orang lain. Bagaimana mereka berlatih hidup mandiri, tidak menjadi beban masyarakat, bahkan dapat mengurangi beban masyarakat. Kegiatan ini masih agak langka dilakukan di perguruan tinggi, dan biasanya hanya dilakukan dengan KKN yang selama kuliah hanya dilakukan sekali; mengingat "waktu dan biaya" yang harus dikeluarkan oleh perguruan tinggi atau oleh mahasiswa. Namun sebenarnya kegiatan ini bisa dilakukan dan dilatihkan dalam bentuk perkemahan bakti untuk waktu yang pendek misalnya 2 atau 3 hari bersama masyarakat desa membuat jlan desa; mengalirkan saluran air minum dari sumbernya ke desa, penyuluhan dan praktik teknik pengolahan sampah sekaligus memanfaatkannya menjadi bio gas, dan sebagainya.

b. Menggunakan metode bermain peran untuk meningkatkan kualitas berpikir (Using the role-play method to promote thinking). Pendidikan ini bisa dilakukan dengan menggunakan metode peran untuk meningkatkan penalaran sebagai sarana penggugah semangat, dan memanusiakan manusia. Kegiatan yang menarik ini dapat merangsang kreativitas mahasiswa untuk menulis skenario, novel, atau bahkan desain pertunjukan akbar yang edukatif.

c. Belajar meningkatkan kecerdasan emosional dan social (Promoting social-emotional learning). Di dalam kelas pendidikan ini agak sulit diterapkan, namun di luar kelas pendidikan ini akan sangat mudah dilakukan/dilatihkan. Pendidikan ini sangat bagus dilakukan di perkemahan, dimana ada pembagian tugas yang baik sehingga semuanya mengalami pengalaman sebagai: juru masak, membersihkan tenda, kegiatan survival, first aids, memimpin dan dipimpin, merencanakan kegiatan, dan kegiatan bakti. Di sini mahasiswa dilatih mengendalikan nafsunya, melatih kesabaran, melatih menghargai orang lain, tidak mencela kekurangannya dan inilah sejatinya yang dimaksud dengan promoting social-emotional learning tersebut. ${ }^{8}$

3. Model Pendekatan Individual (Personal models). Pendidikan ini dilakukan dengan mendidik mahasiswa melalui pengembangan sikapnyasecaraindividu. Baden Powell dalam bukunya "Rovering to success" menyampaikan dalam satu sub judulnya bahwa "Self education is

8 Dasim Budimansyah, dkk, Model Pendidikan Karakter di Perguruan Tinggi, Bandung: Universitas Pendidikan Indonesia,. 2010

RI'AYAH, Vol. 01, No. 01 Januari-Juni 2016 
necessary" yang menyatakan pentingnya pendidikan individu, Tuhan menciptakan manusia untuk menjadi manusia (God made men to be men). Dalam buku "World Adult Resources Handbook"9 disampaikan bahwa pendidikan menggunakan"Self-directed learning", untuk menghadapi kondisi dan situasi lingkungan yang terus berubah. Disinilah pendidikan dijadikan sebagai wahana yang unggul menuju kemandirian, dan menjadi warganegara yang baik. Model ini dilakukan dengan menggunakan:

a. Mengasah keterampilan melalui latihan-latihan memecahkan masalah (Enhancing the problem finding skills). Dalam kegiatan mahasiswa bisa diberikan dengan menggunakan atau memanfaatkan benda-benda di sekitarnya menjadi bentuk-bentuk bangunan misalnya; mereka dilatih secara sistematis dengan membuat perencanaan, menemukan barang yang diperlukan, membuat rencana baru atau rencana pengganti apabila benda-benda yang diperlukan tidak diperoleh, menemukan inovasi, menilai atau menaksir apakah benda-benda yang diperoleh tersebut representatif untuk rencana yang akan dibuat. Disinilah mahasiswa dilatih untuk meningkatkan kualitas keterampilan dengan dihadapkan pada masalah-masalah. Saat ini pelatihan yang semacam ini walaupun mudah tetapi sangat langka dilakukan di perguruan tinggi, padahal latihan ini bisa dilakukan di kelas dan dapat dikaitkan dengan berbagai pokok bahasan yang ada dalam berbagai disiplin ilmu.

b. Improvisasi atau inovasi bahan yang ada/tersedia untuk meningkatkan kreativitas (Handy thinking tools to promote creative problem solving). Pendidikan ini bisa dilakukan di kelas maupun di alam terbuka yang menantang. Disini kreativitas mahasiswa dikembangkan melewati latihan-latihan kecerdasan baik kecerdasan fisik/kinestetik, kecerdasan intelektual, kecerdasan sosial, kecerdasan emosional, bahkan kecerdasan spiritual (learning to multiple intelligences). Disinilah mahasiswa bisa dihadapkan dengan berbagai kasus untuk dipecahkan, atau dibekali dengan instrumen, peta, buku tugas, atau peralatan sederhana mereka belajar untuk memecahkan masalah, belajar hidup mandiri, mereka dibiasakan untuk tahan uji, tidak mudah putus asa, atau menyerah, dan senantiasa berbuat kebaikan. Misalnya diberikan peta dimana disitu ada pemukiman yang dekat sungai dan tanahnya mudah longsor, di sisi lain ada lahan walau jaraknya jauh tetapi bisa dipergunakan untuk pemukiman, masalahnya adalah jauh dari pasar, transportasi masih sulit, dan biaya belum tersedia. Disini mahasiswa diminta untuk membuat 
simulasi proposal ditujukan kepada pemerintah yang secara rinci, dan teknis sehingga bisa memecahkan masalah sosial.

c. Membiasakan berpikir terbuka dalam menganalisis dan memberikan penilaian (Promoting open mindedness in analysing and evaluating arguments). Kegiatan ini dapat membuat mahasiswa menerima sesuatu yang baru, sesuatu yang berbeda, kemudian menilai apakah sesuatu tersebut cocok dengan nilai-nilai yang telah dianutnya di dalam kehidupan mereka. Kegiatannya dapat dilakukan di kelas maupun di luar kelas dalam berbagai disiplin ilmu. Misalnya saja mahasiswa diminta pendapatnya terhadap berbagai tayangan TV apakah kelemahan yang ada di tayangan tersebut ditinjau dari "mass media sebagai alat mencerdaskan keidupan bangsa". Kemudan bagaimana solusinya agar media tersebut dapat memadukan antara kepentingan bisnis dan kepentingan pendidikan, dan bagaimana peluangnya. Disini mahasiswa dihadapkan dengan inovasi-inovasi baru yang akan mereka temukan melalui diskusi, atau studi kepustakaan atau bahkan dengan study tour. Di dalam hal ekonomi dan pembangunan bisa saja mahasiswa diminta untuk mencermati masalah Free Port, pemberantasan korupsi, tata niaga minyak atau hasil tambang lainnya. Dengan demikian mahasiswa akan open minded dalam hal-hal yang menyangkut kebutuhan masyarakat dan masalah-masalah sosial. 


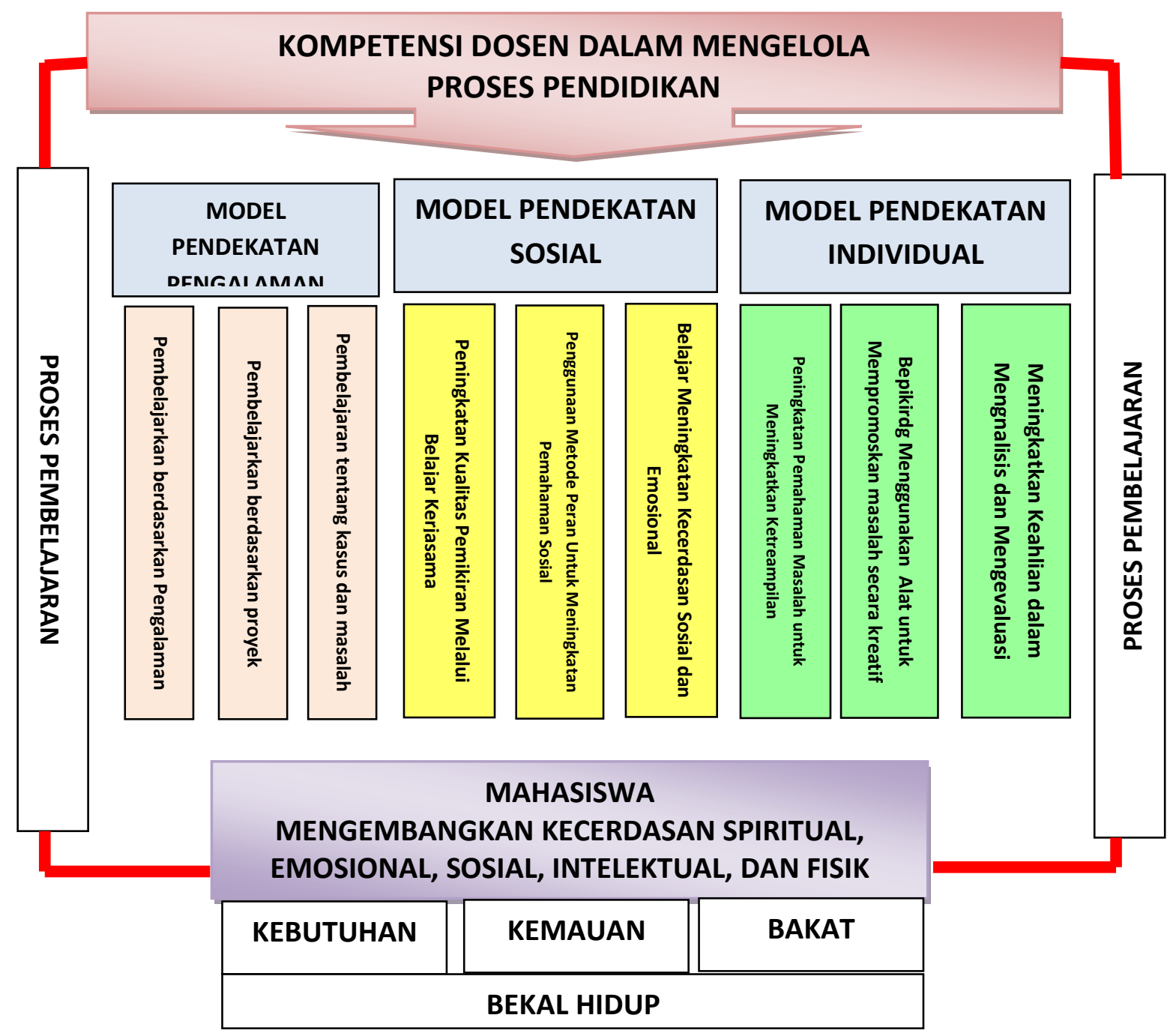

Model tersebut di atas perlu diaplikasikan ke dalam suatu proses pembelajaran mulai dari input - proses - output - outcome - impact.

Pada penyiapan input:

1. Dilakukan revisi materi pembelajaran yang di dalamnya diberi muatan pendidikan karakter, yang dilakukan tidak saja secara teoritis tetapi juga praktis.

2. Perlu adanya pelatihan bagi dosen untuk memadukan science dengan budi pekerti/akhlak mulia baik dalam kegiatan intra kurikuler, ko kurikuler maupun ekstra kurikuler dilengkapi bagaimana menyelenggarakan kegiatan hiden curriculum. ${ }^{10}$

3. Adanya kelengkapan sarana pembelajaran, di dalam dan diluar kelas, pada tahap awal pembelajaran di luar kelas dapat dikmas dengan tanpa menggunakan biaya. Misalnya membuat peta pendidikan, peta ekonomi, 
peta kesejahteraan, peta keamanan, peta budaya, Kota Metro dan sebagainya.

4. Diupayakan suasana yang menunjang, misalnya di luar kelas tidak ribut (menghindari noise); bau yang tidak sedap; ruangan yang terlalu panas, atau terlalu sempit.

\section{Pada kegiatan proses}

Dalam kegiatan ini perlu dikondisikan adanya:

1. Transformasi nilai-nilai dan kecakapan. Selama ini yang dilakukan kebanyakan baru "transfer of knowledge". Oleh karena itu dosen harus menguasai banyak metode latihan. ${ }^{11}$

2. Perencanaan dilakukan secara matang dan inovatif. Setidaknya setiap ajaran baru ada inovasi baru yang semakin baik.

3. Pengaturan dilakukan dalam kegiatan proses penyampaian, praktik, pematangan, pendalaman, dan pengembangan. Dalam kegiatan ini mahasiswa "tidak diberi tahu" tetapi harus "mencari tahu".

4. Koordinasi sebelumnya dilakukan melalui kesepakatan do's dan dont's sehingga di dalam kegiatan proses tidak terjadi kendala yang menjadikan gap information.

5. Kegiatan kontrol dilakukan melalui evaluasi baik yang bersifat test, mauun yang nontest.

\section{Pada proses output}

Di sini ada dua hal yang penting yakni:

1. Mahasiswa harus paham benar apa yang diberikan dan diketahui dari dosen.

2. Mahasiswa merasakan manfaat ilmu pengetahuan yang diperolehnya dalam proses pembelajaran.

\section{Pada Proses Outcome}

Di sini mahasiswa sudah dapat mempraktikkan ilmu pengetahuan yang berupa pengetahuan, keterampilan dan sikap, serta mempraktikkannya di lingkungan pergaulan mereka dan masyarakat di mana ia berada. Di sini mahasiswa sudah tidak menjadi beban keluarga dan masyarakat lagi.

\section{Pada Proses Impact}

Mahasiswa sudah dapat mendesiminasikan, dan menyumbangkan ilmu yang diperolehnya, bahkan memberi contoh yang baik. Muaranya mahasiswa menjadi warga negara yang baik, pancasilais, dan bertanggungjawab atas kesejahteraan masyarakat.

11Penulis telah membuat buku yang berjudul "Sukses Mengajar" yang baik untuk para dosen dan guru, serta para trainer, yang berisikan 104 metode latihan.

RI'AYAH, Vol. 01, No. 01 Januari-Juni 2016 


\section{Proses Pendidikan Karakter di Kampus}

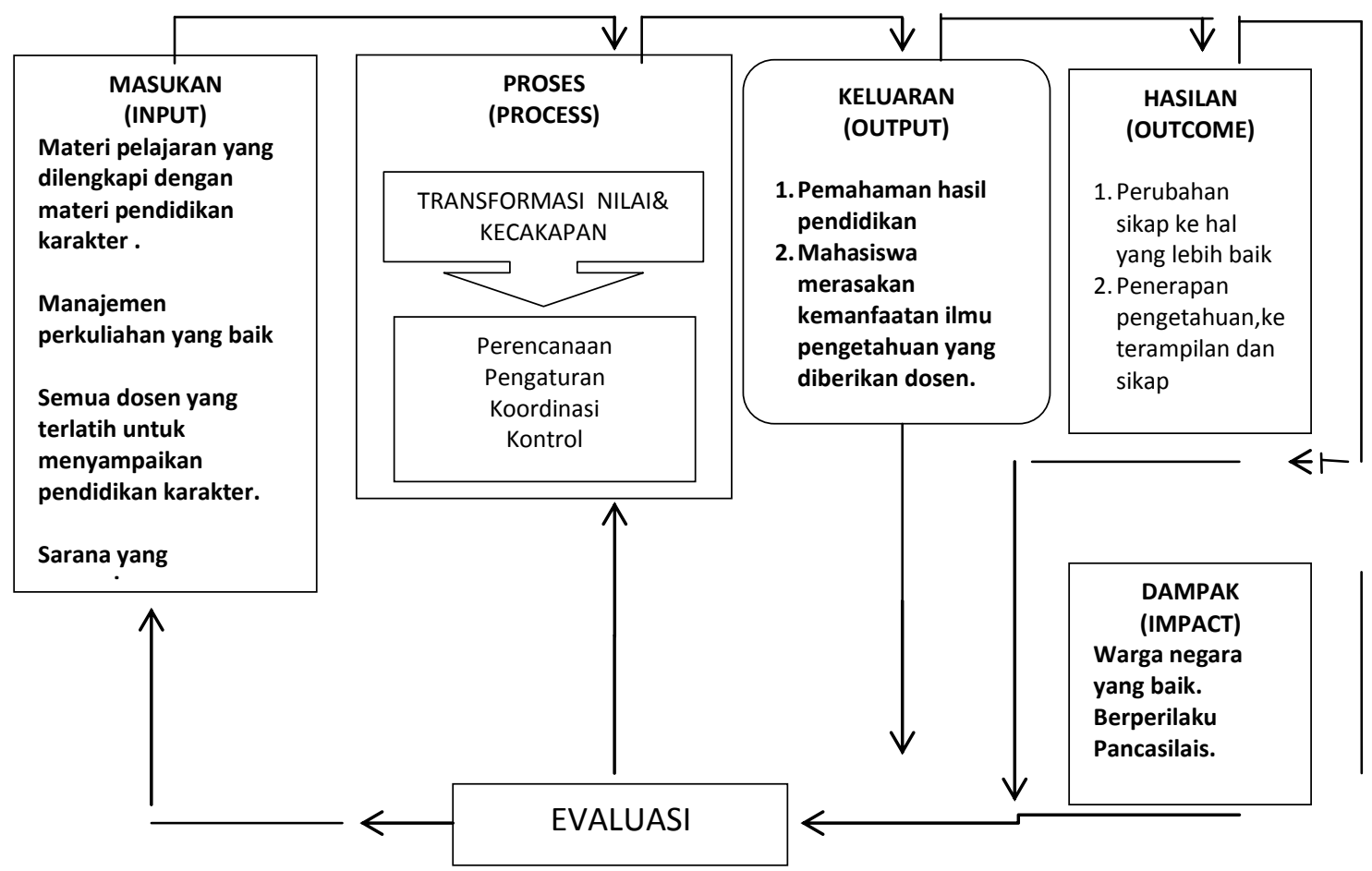

\section{Penutup}

Keberhasilan pendekatan model pengalaman, model sosial, dan model individual, manakala:

1. Para dosen akan memiliki kemampuan menyajikan materi yang diampunya yang lebih variatif dan menarik karena diintegrasikan dengan pendidikan karakter, melalui penerapan inquiry model, social model, dan individual model. Dosen dapat mengemas bahan ajar yang lebih baik dalam mengaplikasikan nilai-nilai yang terkandung dalam Tri Darma Perguruan Tinggi.

2. Dengan penyajian yang menarik maka akan dapat mengurangi kesenjangan hubungan antara dosen dan mahasiswa.

3. Dosen dapat melakukan pendekatan dan bekerjasama dengan instansi/lembaga lain baik yang profit maupun non profit untuk menjembatani kehidupan kampus dan lapangan kerja yang merupakan kehidupan yang sebenarnya di masyarakat.

\section{Daftar Pustaka}

Aini, Neneng Siti Fatimah Nurul, "Pendidikan Karakter dalam Pemikiran Azyumardi Azra", Skripsi, Fakultas Tarbiyah dan Keguruan UIN Sunan Kalijaga Yogyakarta, 2012.

Al-Abrasyi, Athiyah, Dasar-dasar Pokok Pendidikan Islam, Jakarta: Bulan Bintang, 1993. 
Baden Powell. Lord, Rovering to Success, Herbert Jenkins Ltd. 3 Duke of York Street, London, S.W.I, 1922.

Baden Powell. Lord.,Panduan Untuk Pembina Pramuka Penggalang, (Judulasli: Aids to Scout Masterships) disunting oleh: Mun Kusumanti, Joko Mursitho, Dadi Pakar \& Rini Palupi, Penerbit: Pustaka Tunas Media, Balai Penerbit GerakanPramuka, Jakarta, 2012.

Branson, E.J., 1998. Rainbow trout fry syndrome: an update. Fish Vet. J. 1998(2):63-66

Bronson. Richard, 1998, Losing my virginity: How I have survive, Had Fun, and Made a Fortune Doing Bussiness, My Way. ISBN - ISBN 978-0-81296-714-2 London

Dasim Budimansyah, dkk, Model Pendidikan Karakter di Perguruan Tinggi, Bandung: Universitas Pendidikan Indonesia, 2010.

J. Schwartz, Merle (ed), Effective Character Education: A Guidebook for Future Educators, New York: McGraw-Hill Companies, 2008.

Lickona, Thomas dan Matthew Davidson, Smart E Good High School: Integrating Excellence and Ethics for Success in Schools, Work, and Beyond. Cortland: Center for 4th and 5th Rs, 2004.

World Scout Bureau, Worlds Adult Resources Handbook. Geneva, 2005. 